\title{
CLIENTS’ EMPIRICISM TOWARDS UPI PLATFORMS
}

\author{
Praveen M.V ${ }^{1}$, Gopika.MK ${ }^{2} \&$ Mahesh. P. B ${ }^{3}$ \\ ${ }^{1}$ Asst.Professor, PG\& Research Department of Commerce, Govt. College Madappally, \\ Kozhikode, Kerala, India, 9745086530 \\ ${ }^{2}$ Post Graduate Student, PG\& Research Department of Commerce, Govt. College \\ Madappally, Kozhikode, Kerala \\ ${ }^{3}$ Asst.Professor, PG\& Research Department of Commerce, Govt. College Madappally, \\ Kozhikode, Kerala
}

Article DOI: $\underline{\text { https://doi.org/10.36713/epra8479 }}$ DOI No: 10.36713/epra8479

\begin{abstract}
The purpose of the study is to examine the awareness, perception and satisfaction level of clients of popular UPI platforms. Satisfied clients are the biggest promoters in today's fast-changing competitive market. Their favourable wordof-mouth provides legitimacy, appeal, and aids in the acquisition of new clients to the business. The Unified Payment System (UPI) is designed to build a platform for cashless and transparent financial transactions by using the advantages of mobile technology. So, this study is based mostly on primary data collected from 100 samples from UPI clients in Kerala through structured questionnaire and the secondary data used only for theocratical frame. The key tools for data analysis is statistical tool like One-way ANOVA and weighted averages. Study result reveals the significant influence of educational status of the clients in their awareness of UPI platforms and its services. The study also observes the age and gender effect on the satisfaction and perception of clients.

KEYWORDS: Unified Payment Interface (UPI), UPI Platforms, Client satisfaction, Client Perception, Digital inclusion.
\end{abstract}

\section{INTRODUCTION}

Advanced technology has altered the payment mode of India. The post-demonetization period (after November 8, 2016) had a significant impact in the expansion of digital payments in India. Smart phones, which have become an inextricable part of everyone's personal, professional, and financial online lives, are widely used to make digital payments. One touch payment was made possible by the widespread availability of internet connections, one-touch access, and secure financial transactions. As a result, the Indian government has built a significant system known as the "UPI" (Unified Payment Interface), which aims to offer a platform for cashless and transparent financial transactions. In August 2016, the National Payments Corporation of India (NPCI) launched the Unified Payment Interface (UPI), a next-generation mobile-based payment system that allows account holders from different banks to send and receive money using their Aadhar unique identification number, mobile phone number, or virtual payment address without having to enter their bank account.

Customer satisfaction is a metric that measures how happy customers are with a company's products, services, and capabilities. Customer satisfaction data comprises surveys and ratings, which aid a business in identifying areas for improvement or modifications to its products and services. Customer satisfaction data comprises surveys and ratings, which aid a business in identifying areas for improvement or modifications to its products and services. Customers that are happy with your service are your best advocates in today's competitive industry. Their favourable word-of-mouth gives your business credibility and appeal, as well as assisting in the acquisition of new clients. This saves the brand a significant amount of money that would otherwise be 
spent on marketing and promotional initiatives to attract new clients.

\section{REVIEW OF LITERATURE}

Bamasak (2011) opined that m-payment has a brighter future and the unlawful use of mobile phones as well as the security of mobile phone payments were major obstacles in the progress of the digital payment system. Liu et al. (2012) found that the digital wallet payments provide additional convenience to consumers by giving various payment alternatives and boosting transaction speed. Padashetty and Kishore (2013) observed that the simplicity of use, expressiveness, and trust affected wallet adoption and functioned as motivators to use digital payment.

Khalil Ahmad and Khuram Shafiq (2015) in their study titled "Is Plastic Money Important in Consumer Purchasing Behaviour?" provides confirming evidence that purchasers feel good about buying with plastic cash because of the ease of access to money, the lack of cash carrying hazards, and the reward purchasing. Rouibah (2015) revealed the important primary restrictions affecting payments were lack of security, lack of trust, fear of failure, excessive costs and lack of familiarity. Furthermore, internet security, banking facilities, privacy, and service quality were all factors influencing e-payment acceptance.

Kunal Taheam, et al. (2016) in the study titled "Drivers of Digital Wallet Usage: Implications for Leveraging Digital Marketing" observed several factors that influenced people to use electronic wallets to make payments. The study highlights the preference on sophisticated wallets by Panjabi users due its usefulness, security, social effect and other consideration.

Ravish Rana (2017) found through their study that consumer educational status influences digital payment acceptance. If a person has completed his or her secondary education and is computer aware, he or she will be more likely to choose the digital payment option. It was also shown that in places/regions with a high level of education, such as Delhi NCR and other urban areas, the probability of accepting digital payments is significantly higher. The increase in Smartphone users and internet availability in such areas has also aided in the acceptance of digital payment. Singh (2017) observed that there was a substantial difference between consumer education and digital payment acceptance. Consumer perception of digital payment has a favourable and significant impact on consumer adoption of digital payment.

\section{RELEVANCE OF THE STUDY}

Digital India has ushered in a cashless society. The idea behind a cashless economy is to make India a better place. Being paperless leads to an increase in the usage of digital banking and cashless transfers, and the launch of UPI is expected to impact the cashless transfer tremendously. It allows bank customers to send and receive money in real time using their smartphones. There are more than a billion mobile connections, with 240 million smartphone users, and this number is likely to more than double in the next years. Why this works is because there are large scale fibre optic network initiatives and Pradhan Mantri Jan Dhan Yojana has provided infrastructure for universal access to banking. Individuals can pay their day-to-day expenses such as bill payments, fund transfers, and so on digitally thanks to the ease and convenience of using UPI. The majority of people now use Paytm, Phonepe, Google Pay, Mobikwik, the BHIM app, and other similar services. All of the above mobile payment apps accept payments via the UPI payment system. Thus, in this context, the current study is extremely important because it attempts to study and comprehend customer attitudes towards various UPI services.

\section{RESEARCH PROBLEM}

India took a step closer to the digital economy with the launch of UPI. Kerala is regarded as a consumer state with a literacy rate of $100 \%$. Customers are highly opinionated, they compare and select the most convenient, user-friendly, and secure services. As a result, it's vital to understand the intensity of UPI transactions acceptance in Kerala. There have been no substantial studies on this subject. The purpose of this study is to determine Keralites' adoption of UPI and their opinion on UPI services.

\section{RESEARCH OBJECTIVES}

There are three objectives in the present study.

1. To identify the clients' awareness, preference and perception of UPI platforms.

2. To understand the satisfaction level of UPI clients.

3. To analyse the age, gender and educational effect on awareness and satisfaction level of UPI Clients.

\section{RESEARCH HYPOTHESES}

There are three hypotheses set for the study.

1. H01: There is no significant difference in awareness level of UPI clients according to their education status.

2. H02: There is no significant difference in satisfaction level of UPI users according to their age. 3. H03: There is $\mathrm{np}$ significant difference in satisfaction level of UPI users according to their gender.

\section{RESEARCH METHODOLOGY}

The research design of this study is structured as: 


\subsection{Research Approach}

The research approach used for the study is sample method. The study is basically descriptive research design.

\subsection{Sampling Size}

The sample size is limited to 100 UPI users of Kannur in Kerala. Out of 100 samples 50 samples are male and 50 samples are female UPI users.

\subsection{Sampling Technique}

The sampling technique adhered by the study is purposive sampling.

\subsection{Collection of data}

In this study primary data and secondary data were used. The primary data were collected by serving questionnaire among UPI users and secondary data were collected from the available literature, journals and websites of RBI and NPCI.

\subsection{Tools of analysis}

The analysis is carried out with percentage analysis, statistical tools, the difference in satisfaction level of UPI users according to their age and gender is analysed through ANOVA test.

\subsection{Scope of the study}

The scope of the study is to know the awareness, perception and satisfaction level of clients towards the UPI platform, to study the most preferred UPI application, to understand the reasons for choosing the specified UPI platform and this study also gives emphasis to study the gender effect and age effect on satisfaction of UPI clients in Kannur district of Kerala state.

\section{RESULT AND DISCUSSION}

This section deals with the analysis and discussion of collected data. The table below depicts the analysis and inference of this study using SPSS Statistical 22.0 software represented with help of tables, graphs and its interpretation. In this study primary data is used for analysis and interpretation of data.

\subsection{Demography of Respondents}

Table 1: Demographic Profile of Respondents

\begin{tabular}{|c|c|c|c|}
\hline Q. No & Criteria & Category & $\begin{array}{c}\text { No. of } \\
\text { Respondents }\end{array}$ \\
\hline \multirow[t]{4}{*}{1} & Age & 20-30 years & 28 \\
\hline & & $30-40$ years & 25 \\
\hline & & $40-50$ years & 21 \\
\hline & & Above 50 years & 26 \\
\hline \multirow[t]{2}{*}{2} & Gender & Male & 50 \\
\hline & & Female & 50 \\
\hline \multirow[t]{5}{*}{3} & Education & SSLC & 17 \\
\hline & & Plus Two & 18 \\
\hline & & Graduation & 39 \\
\hline & & Post-Graduation & 18 \\
\hline & & Above Post Graduation & 8 \\
\hline \multirow[t]{6}{*}{4} & Occupation & Student & 15 \\
\hline & & Govt Employee & 15 \\
\hline & & Private Employee & 23 \\
\hline & & Business & 8 \\
\hline & & Unemployed & 19 \\
\hline & & Others & 20 \\
\hline \multirow[t]{4}{*}{5} & Income & Less than 10000 & 25 \\
\hline & & $10000-25000$ & 30 \\
\hline & & $25000-50000$ & 27 \\
\hline & & Above 50000 & 18 \\
\hline
\end{tabular}

Source: Primary Data)

Table1 shows that are 50 male and 50 female respondents out of which most of the respondents belongs to age group of 20-30 (28 per cent) years. Majority of respondents possess graduation (39 per cent) and are private employees (23 per cent) and others (20 per cent) consists of respondents having earning through SHG, NREGA and pensioners including social security pensions. Most of the respondents belongs to income group of 10,00025,000 rupees. 75 per cent of respondents having income above Rs.10,000. 
8.2. Clients' Awareness Level

Table 2 Clients' Awareness Level

\begin{tabular}{|c|c|c|}
\hline Level of Awareness & Frequency & Percent \\
\hline Not at all aware & 5 & 5.0 \\
Slightly aware & 24 & 24.0 \\
Moderately aware & 43 & 43.0 \\
very much aware & 23 & 23.0 \\
Extremely aware & 5 & 5.0 \\
Total & 100 & 100.0 \\
\end{tabular}

(Source: Primary Data)

\section{Graph 1: Level of Awareness}

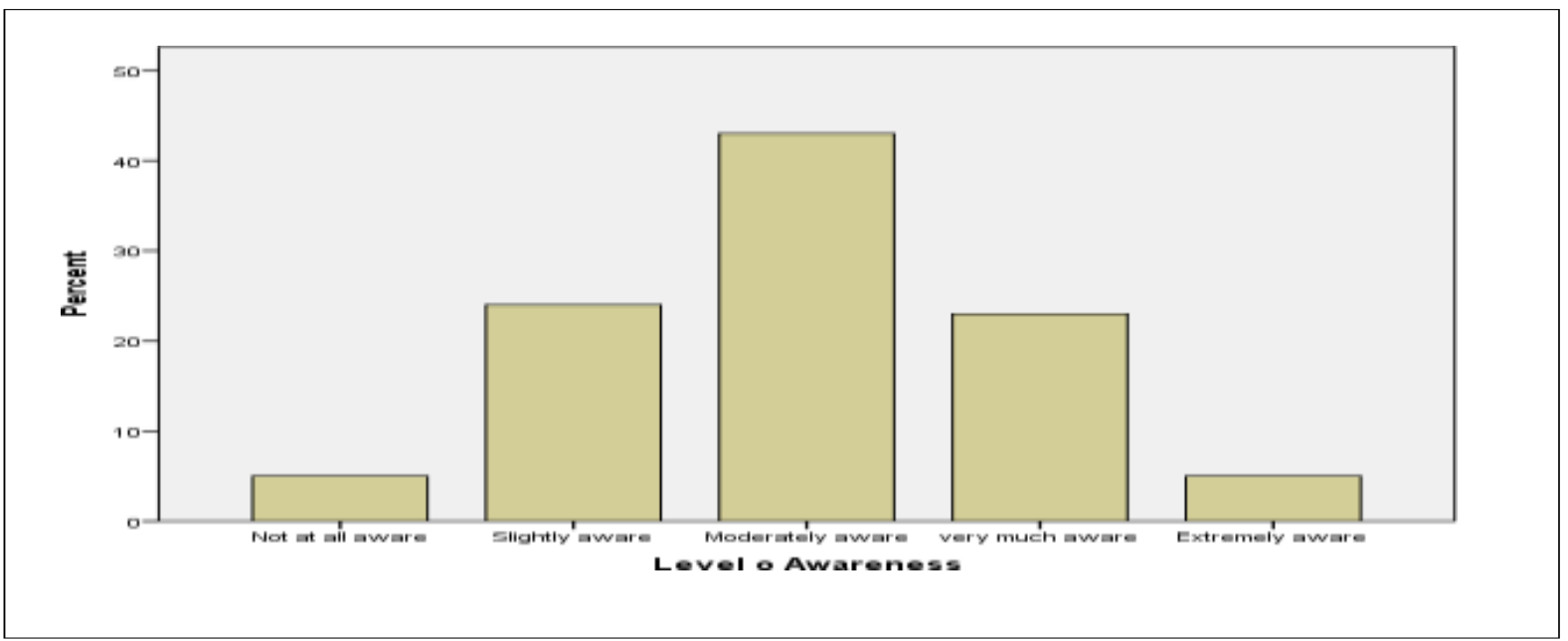

(Source: primary data)

The table 2 and graph 1 shows the awareness level of respondents. Only five percent of respondents are not at all aware and extremely aware about UPI platform. Whereas, 24 percent are and 43 percent of respondents are slightly and moderately aware about UPI respectively and the 23 percent of respondents are very much aware about UPI platform. As a whole 95 per cent of clients having awareness on UPI platforms at varied degrees.

H01: There is no significant difference in awareness level of UPI users according to their education status.

Table 3: Effect of education on awareness level of UPI user

\begin{tabular}{|c|c|c|c|c|c|}
\hline Awareness on UPI & Sum of Squares & df & Mean Square & F & Sig. \\
\hline Between Groups & 11.988 & 4 & 2.997 & 3.796 & .007 \\
Within Groups & 75.002 & 95 & .789 & & \\
Total & 86.990 & 99 & & & \\
\hline
\end{tabular}

(Source: Primary data)

Here the $p$ value 0.007 is less than table value 0.05 . Therefore, we reject null hypothesis and accept alternative hypothesis. So, it can be concluded that there is significant difference in awareness level of UPI clients according to their education status. 


\subsection{Clients' Preference of UPI Platforms.}

Table 4: Clients' preference of UPI Platforms.

\begin{tabular}{|c|c|c|}
\hline Most preferred UPI application & Frequency & Percent \\
\hline Google Pay & 45 & 45.0 \\
PhonePe & 17 & 17.0 \\
BHIM & 4 & 4.0 \\
Paytm & 16 & 16.0 \\
iMobile & 1 & 1.0 \\
Yono SBI & 17 & 17.0 \\
Amazone Pay & 0 & 0.0 \\
Total & 100 & 100.0 \\
\hline
\end{tabular}

(Source: primary data)

Graph 2: Clients' preference of UPI Platforms

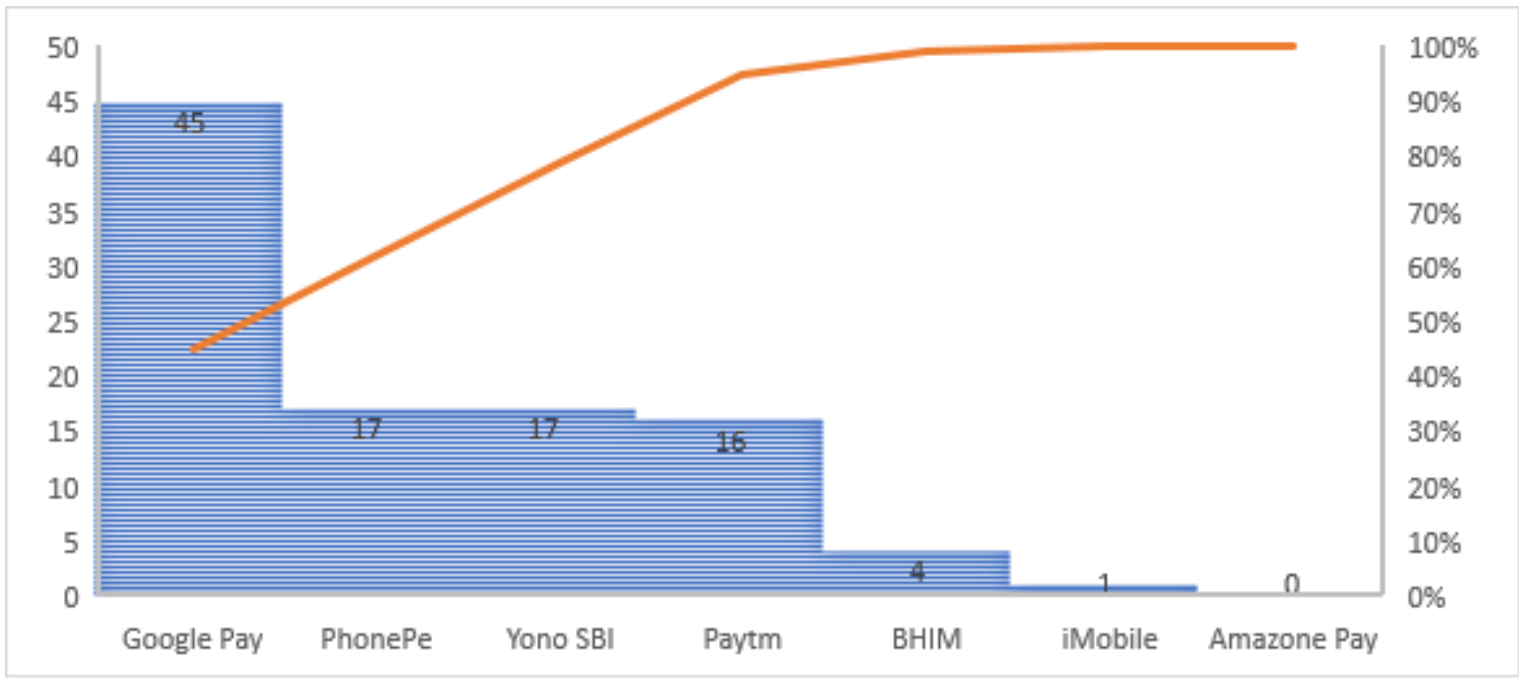

(Source: Primary data)

This result shows that the most preferred UPI application (45 percent of the respondents) is Google Pay, 17 per cent each prefers Phone Pe and Yono
SBI, followed by Paytm (16 per cent). 4 per cent prefers BHIM application. While one per cent prefer iMobile, none of the respondent prefers Amazon Pay.

\subsection{Clients' Perception towards UPI Platforms}

Table 5: Clients' Perception

\begin{tabular}{|l|c|c|}
\hline Statements & Yes & No \\
\hline Allows Instant fund transfer & 74 & 26 \\
\hline Allows 24-hour services & 81 & 19 \\
\hline Provides Time benefit & 67 & 33 \\
\hline Allows Free fund transfer & 42 & 58 \\
\hline Decreasing fraud & 5 & 95 \\
\hline
\end{tabular}

(Source: Primary Data) 
Table 6: Clients' perception towards UPI facilities

\begin{tabular}{|c|c|c|c|c|c|c|c|}
\hline Statement & $\begin{array}{l}\text { Never } \\
\text { (1) }\end{array}$ & $\begin{array}{c}\text { Rarely } \\
\text { (2) }\end{array}$ & $\begin{array}{l}\text { Sometimes } \\
\text { (3) }\end{array}$ & $\begin{array}{l}\text { Often } \\
\text { (4) }\end{array}$ & $\begin{array}{l}\text { Always } \\
\text { (5) }\end{array}$ & $\begin{array}{l}\text { Total } \\
\text { Score }\end{array}$ & Rank \\
\hline $\begin{array}{c}\text { Account transfer } \\
\text { facility }\end{array}$ & 7 & 7 & 29 & 29 & 28 & 364 & III \\
\hline $\begin{array}{c}\text { Account balance } \\
\text { enquiry facility }\end{array}$ & 3 & 11 & 27 & 24 & 35 & 377 & I \\
\hline Recharging facility & 5 & 15 & 27 & 19 & 34 & 362 & IV \\
\hline $\begin{array}{c}\text { Online payment } \\
\text { facility }\end{array}$ & 2 & 7 & 35 & 25 & 31 & 376 & II \\
\hline Messaging facility & 48 & 26 & 17 & 7 & 2 & 189 & V \\
\hline \multicolumn{3}{|c|}{ Max.score $=500(100 * 5)$} & \multicolumn{3}{|c|}{ Perception Mean Score } & \multicolumn{2}{|c|}{333.60} \\
\hline
\end{tabular}

(Source: Primary data)

The tables 5 and 6 reveals that clients have relatively good perception towards the facilities of UPI platforms as perceived mean score comes to 333.60 out of 500 . 95 percent of the respondents perceives that use of UPI platforms never decreases the chances of fraud transactions. Total perception score is minimum (189) in the case of messaging facility and it indicates that messaging facility provided by most of the UPI platforms are insufficient or not up to mark. All other facilities scores above 70 per cent (362 to 377 ) of the expected maximum scores of clients' perception which in turn hints the clients are moderately satisfied.

\section{5. Clients' Satisfaction on UPI Platforms}

Table 7: Clients' satisfaction level

\begin{tabular}{|c|c|c|}
\hline Satisfaction level of respondents & Frequency & Percent \\
\hline Not at all satisfied & 0 & 0.0 \\
Slightly satisfied & 5 & 5.0 \\
Moderately satisfied & 48 & 48.0 \\
Very satisfied & 44 & 44.0 \\
Completely satisfied & 3 & 3.0 \\
Total & 100 & 100.0 \\
\hline
\end{tabular}

(Source: Primary Data)

Table 7 shows satisfaction level of clients on the UPI platform services. There is no respondent who are fully dissatisfied with the UPI use, 5 per cent slightly satisfied, 48 per cent are moderately satisfied
44 percent are very satisfied and only 3 per cent are completely satisfied with their UPI use. 
8.5.a: Age effect on satisfaction level of UPI clients

H02: There is no significant difference in satisfaction level of UPI clients according to their age.

Table 8: Age effect on satisfaction level of respondents

\begin{tabular}{|c|c|c|c|c|c|}
\hline $\begin{array}{c}\text { Satisfaction level of } \\
\text { UPI user }\end{array}$ & Sum of Squares & df & Mean Square & F & Sig. \\
\hline Between Groups & .307 & 3 & .102 & .243 & .866 \\
Within Groups & 40.443 & 96 & .421 & & \\
Total & 40.750 & 99 & & & \\
\hline
\end{tabular}

(Source: Primary Data)

Here the $\mathrm{p}$ value 0.866 is more than table value 0.05 . Therefore, we accept null hypothesis. So, it can be concluded that there is no significant difference in satisfaction level of UPI users according to their age.

8.5.b: Gender effect on satisfaction level of UPI clients

H03: There is no significant difference in satisfaction level of UPI users according to their gender.

Table 9: Gender effect on Satisfaction level of respondents

\begin{tabular}{|c|c|c|c|c|c|}
\hline $\begin{array}{c}\text { Satisfaction level of } \\
\text { users }\end{array}$ & Sum of Squares & df & Mean Square & F & Sig. \\
\hline Between Groups & .250 & 1 & .250 & .605 & .439 \\
Within Groups & 40.500 & 98 & .413 & & \\
Total & 40.750 & 99 & & & \\
\hline
\end{tabular}

(Source: Primary Data)

Here the $\mathrm{p}$ value 0.439 is more than table value 0.05 . Therefore, we accept null hypothesis. We reject alternative hypothesis. So, it can be concluded that there is no significant difference in satisfaction level of UPI users according to their gender.

\section{CONCLUSION}

The study is carried out to analyse the level of awareness, preference, perception and satisfaction of UPI clients in Kerala towards important UPI platforms. The required data were collected by serving questionnaire to 100 UPI clients selected by using purposive sampling. Three relevant hypotheses were set for the study and were tested by using One way Analysis of variance (One Way ANOVA). Tables and graphs are also used to support the analysis. The study reveals that there is a significant influence of educational status of the clients on the awareness level about various UPI platforms and their facilities and services. The study reveals that the UPI clients are discomfortable with the fraud reduction facilities and messaging facilities of most of the UPI platforms. The study observed that most of the UPI clients are moderately satisfied with the UPI platforms under this study and its facilities.
However, there are no significant influence of age and gender of the clients on their satisfaction level. In order to attain an effective digital inclusion, the UPI platforms are required to impart digital confidence among clients by the prevention of fraud and provision of add-on facilities.

\section{REFERENCES}

1. Dewan, S. G., \& Chen, L. D. (2005). Mobile payment adoption in the US: A cross-industry, cross platform solution. Journal of Information Privacy and Security, 1(2), 4-28.

2. Dahlberg, T., Mallat, N., Ondrus, J., \& Zmijewska, A. (2008). Past, present and future of mobile payments research: A literature review. Electronic commerce research and applications, 7(2), 165-181.

3. Das, A., \& Agarwal, R. (2010). Cashless payment system in India-A roadmap.

4. Bamasak, O. (2011). Exploring consumers acceptance of mobile payments-an empirical study. International Journal of Information Technology, Communications and Convergence, 1(2), 173-185.

5. Liu, S., Zhuo, Y., Soman, D., \& Zhao, M. (2012). The consumer implications of the use of 
electronic and mobile payment systems. Rotman School of Management, University of Toronto.

6. Padashetty, S., \& Kishore, K. S. (2013). An empirical study on consumer adoption of mobile payments in Bangalore city-A case study. Researchers World, 4(1), 83.

7. Shafiq, K., \& Ahmad, K. (2015). Is plastic Money Matter for Consumer Buying Behavior? An Empirical Analysis from Pakistan. Bulletin of Business and Economics (BBE), 4(4), 232-237.

8. Taheam, K., Sharma, R., \& Goswami, S. (2016). Drivers of digital wallet usage: Implications for leveraging digital marketing. International Journal of Economic Research, 13(1), 175-186.

9. Mukhopadhyay, B., \& Rath, S. (2011). Role of MFIs in financial inclusion. Review of Market Integration, 3(3), 243-286.

10. Arvind, M. B. L., \& Rajesh, R. CUSTOMER'S PERCEPTION OF UPI AS A DIGITAL MODE OF PAYMENT (WITH REFERENCE TO COIMBATORE DISTRICT).

11. Rathore, S, S. (2016). Appropriation of Cashless transactions By Consumers, 11(7), 413-432.

12. Sunil, K. (2018). Consumer Behaviour towards cashless transactions.

13. Balaji, K. C., \& Balaji, K. (2017). A study on demonetization and its impact on cashless transactions. International Journal of Advanced Scientific Research \& Development, 4(3), 58-64.

14. Mohapatra, S. (2017). Unified Payment Interface (UPI): A cashless Indian e-transaction process. International Journal of Applied Science and Engineering, 5(1), 29-42.

15. Kakadel, R. B., \& Veshne, N. A. (2017). Unified Payment Interface (UPI)-A Way Towards Cashless Economy. International Research Journal of Engineering and Technology, 4(11), 762-766.

16. Thomas, R., \& Chatterjee, A. (2017). Unified payment interface (UPI): a catalyst tool supporting digitalization-utility, prospects \& issues. International Journal of Innovative Research and Advanced Studies, 4(2), 192-195.

17. Singh, S., \& Rana, R. (2017). Study of consumer perception of digital payment mode. Journal of internet banking and commerce, 22(3), 1-14.

18. Saurabhi, A. (2018). A Fresh Scheme via Merchants to Help BHIM Gain Currency again, Economic Times (28/8/2018)

19. Shruti A, Kesavan. (2018) The Future of UPI Payments in India, (3 Sep,2018).

20. https://www.instamojo.com/blog/future-of-upipaymentsindia-growth-expect

21. Cash deals cost $1.7 \%$ of GDP: Visa, https://www.businessstandard.com/article/econo my-policy/cash-deals-cost-1-7-ofgdp-visa116100500617_1.html 